\title{
平板の面内逐次打点曲げにおける打撃角度の影響
}

\author{
金 英俊 ${ }^{*}$ 小山 純一 $^{*}$ 久保木 孝 ${ }^{* *}$ 村田 眞 ${ }^{* *}$
}

\section{Effect of Beating Angle on Incremental In-Plane Bending of Sheet Metal}

\author{
Yingjun JIN*, Junichi KOYAMA*, Takashi KUBOKI ${ }^{* *}$ and Makoto MURATA* ${ }^{* *}$
}

(Received on September 27, 2006)

\begin{abstract}
Incremental in-plane bending, which was developed by the authors, is a new flexible manufacturing technology for the small-lot production of sheet metals with various bending radii. A sheet metal is bent incrementally by inclined punch beating. Beating angle is an important factor of in-plane bending. The effects of beating angle on in-plane bending were investigated. Beating force, the distribution of thickness strain and bending radius were experimentally determined. It was clarified that beating angle is an important factor that affects bending radius. Moreover, deformation simulation was carried out and the effect of beating angle on the in-plane bending mechanism was compared with experimental result. It was found that there is a critical beating angle for obtaining the minimum bending radius for fixed indentation and width of sheet metals.
\end{abstract}

Key words : sheet metal forming, in-plane bending, incremental forming, beating angle, bending radius.

\section{1. 緒 言}

近年 , 加工技術の高度化および製品の多樣化に伴って， CNC(Computer Numerically Controlled)方式の加工機械を用 いるフレキシブルな曲げ加工技術が注目されている . 曲げ 加工は塑性加工の中の基本要素技術である . 曲げ加工にお いて, 板材の曲げ加工は単純, かつ基本的な加工法である . 板材の曲げ加工は, 板面に垂直な方向に曲げる面外曲げと 板面の面内方向に曲げる面内曲げに分けられる . 面外曲げ においては, 板材の知能化 $\mathrm{V}$ 曲(げ加エシステム ${ }^{1), 2)}$, フレキ シブルL曲(゙加工システム ${ }^{3)}$, 繰返し曲(ボ成形装置4)など , 多くの加工法が考案, 研究され実際の工業生産に使用され ている．これに対し, 面内曲げは, 面内での曲げ岡性が面 外への曲げ岡性に比べて著しく大きく, 座屈, 割れ等の不 良現象が発生しやすいため，あまり応用されてない(5) 15)． 面内曲(゙加工は，これまでに，逐次鍛造法 ${ }^{6), 7)}$, 回転引曲(゙ 8), 9) とロール曲(ナ゙10), 圧延曲(ナ゙11) 15)等によって行われてい る. 回転引曲げおよびロール曲げでは, 平板を部分的に逐 次曲げをしていくため, 塑性変形が進行する領域を短く抑 えることができ, 座屈の発生を軽減できる5).しかしなが ら,回転引曲げは平板を順次ドラムに巻き付けていくため, 圧縮側に座屈変形が発生する.軸引張りを加えれば, 圧縮 側の座屈は防止できるが, 引張り側ではくびれや割れが生 じやすくなる ${ }^{8), 9)}$.ロール曲(゙では, 断面比が大きいほど弾 性域で横座屈が生じやすく，面内曲げにおける加工限度は

*(株)アマダ $\bar{\top} 259-1196$ 伊勢原市石田 200

AMADA Co. Ltd. , 200 Ishida, Isehara-shi 259-1196, Japan.

**電気通信大学知能機械工学科 $\overline{1} 182-8585$ 調布市調布ヶ丘 1-5-1

Department of Mechanical Engineering and Intelligent Systems, UEC, 1-5-1 Chofu-shi 182-8585, Japan.
小さくなる .さらに , 積極的な軸引張りの付加は困難であ るため，断面比に関する制限は大きい ${ }^{10)}$.

光こで著者らは, 板材の新しい逐次打点曲げ加工法を考

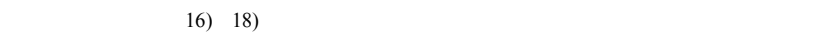
を有するパンチに打撃され，パンチの傾きにより，平板の 幅の方向に肉厚が変化することにより, 面内曲げ加工が行 われる. 光のため, パンチの打撃角度は平板の曲げ半径を 制御する重要な加工条件である.

本論文では逐次打点曲げ加工法を面内曲げ加工に適用し， パンチの打撃角度が曲げ半径に及ぼす影響を調べる . 同時 に, 静的陰解法による FEM シミュレーションを行い, 実 験結果と比較する. 兴の結果から, 面内曲げ加工の変形挙 動を調べ, 打撃角度が曲げ半径に及ぼす影響を明らかにす る.さらに, 逐次打点曲げ加工において, 最適な打撃角度 を調べる .

\section{2. 実験加工機および実験方法}

\section{1 実験条件}

試作した実験加工機の概略図を Fig. 1 に示す . 本加工機 ではパンチ(6) ACサーボモータ(4)と打撃装置8)によって 駆動され上下運動し, 平板(3)はACサーボモータ(1)と送り装 置(2)によって送られ , パンチに打撃され曲げ加工される . 平板は Fig. 2 に示す傾きを有するパンチによって打撃され ると, 平板の打撃部 $\mathrm{A}$ と末打撃部 B おいて, 変形量に差 が生じる. 光のため, 平板の打撃部 A の長手方向の伸びが 未打撃部 B より大きくなり, 平板は同図に示すように面内 曲げ加工がなされる .

本研究では打撃角度か変形形態に及ぼす影響を明らかに するため, 弚の他の加工条件は一定として, 実験を行う. 


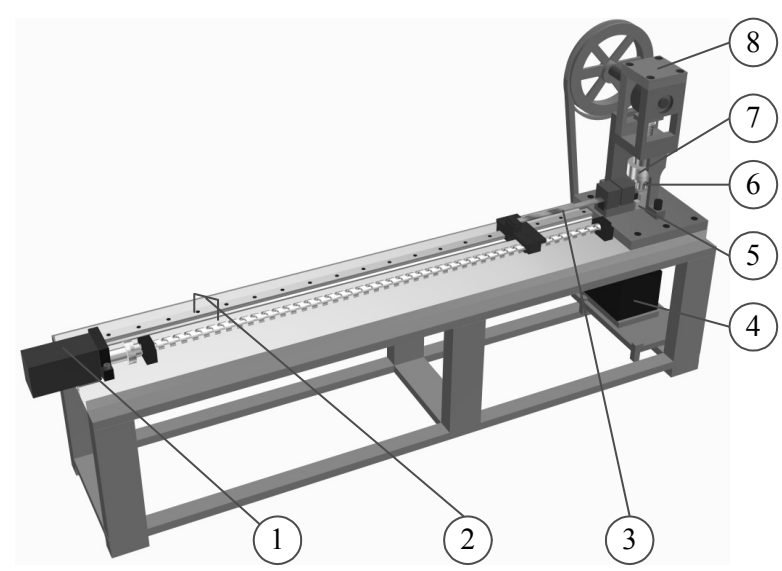

(1) AC servo-motor for feeding (2) Feeding equipment

(3) Sheet metal (4) AC servo-motor for beating (5) Die

(6) Punch (7Load-cell (8) Beating equipment

Fig. 1 Sketch of experimental set-up

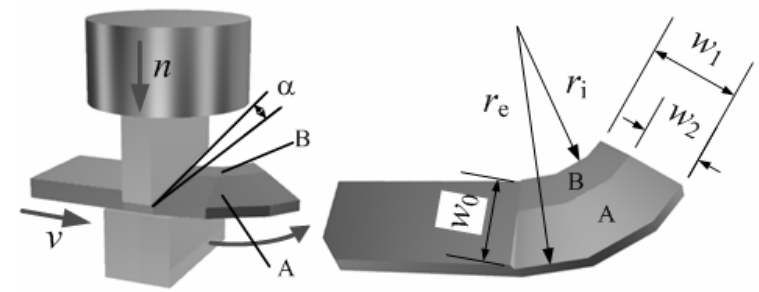

Fig. 2 Schematic illustration of incremental in-plane bending

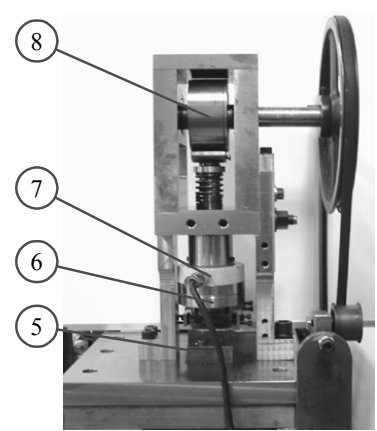

Fig. 3 Photograph of beating equipment of experimental set-up

Table 1 Mechanical properties of material

\begin{tabular}{lc|c}
\hline Proof stress & $\sigma_{0.2} / \mathrm{MPa}$ & 132 \\
\hline Tensile strength & $\sigma_{\mathrm{B}} / \mathrm{MPa}$ & 142 \\
\hline Total elongation & $\delta / \%$ & 14 \\
\hline
\end{tabular}

パンチの打点数を $250 \mathrm{bpm}$ (beat per minute) に固定する. 打点数とは一分間にパンチが平板を打撃する回数である. 平板の送り速度を調節することによって, 打撃ピッチ $p$ が 制御される.打撃ピッチ $p$ を $0.5 \sim 3.5 \mathrm{~mm}$ の範囲で変化さ せる . パンチは幅 $w_{\mathrm{p}}=10.0 \mathrm{~mm}$, 長さ $l_{\mathrm{p}}=30.0 \mathrm{~mm}$ である . パ ンチ打撃面の傾き角度を打撃角度 $\alpha$ 定義し，パンチの打 撃角度 $\alpha$ を 1 度から 4 度まで, 0.5 度毎に変化させる. 本加 工機では, Fig. 3 に示すようにパンチ(6)とダイ(5)の隙間を 調節して，パンチの押込み量を設定する．押込み量 $s$ を $0.73 \mathrm{~mm}$ に，無潤滑で面内曲げ加工を行う . 供試材として, 板厚 $t_{0}=2 \mathrm{~mm}$, 板幅 $w_{0}=25.0 \mathrm{~mm}$ の 1050 アルミニウム合金

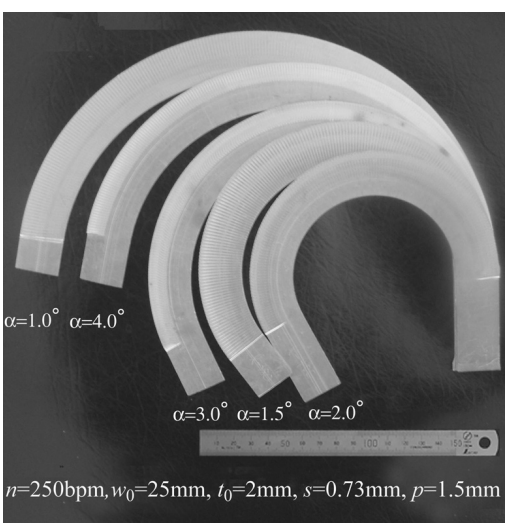

Fig. 4 Photograph of formed sheet metal by incremental in-plane bending

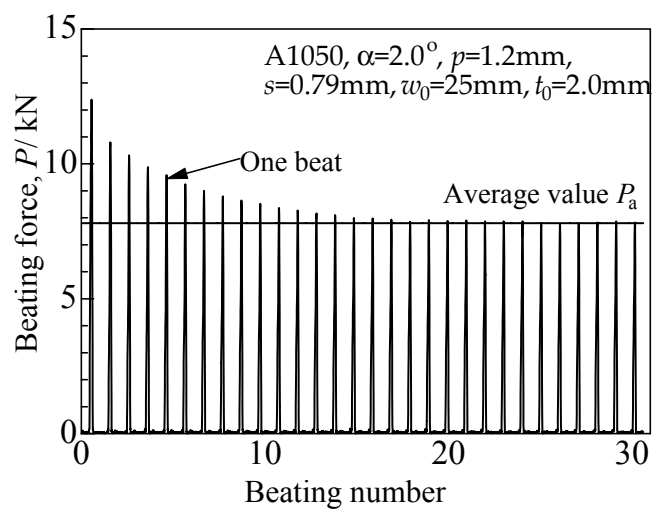

Fig. 5 Variation of beating force during in-plane bending

板材(JISH18)を用いた．平板は素材の圧延方向に対して垂 直に採取している．平板の機械的性質を Table 1 に示す．

本加工法によって曲げ加工された平板の写真を Fig.4に 示す . パンチの打撃角度を変えることにより, 種々の曲げ 半径に加工できる. 打撃角度が 2 度の時, 曲げ半径が最も 小さい.

\section{2 解析条件}

Wales 大学 Swanssea 校において開発された汎用有限要素 法コード ELFEN3.4 を使用し, 静的陰解法による 3 次元弾 塑性解析を行い, 実験結果と比較する . 材料のヤング率 $71 \mathrm{GPa}$, ポアソン比 0.34 とし, 工具 (パンチ) と材料間の 摩擦係数は 0.1 とする. 材料の加工硬化特性は引張り実験 から応力 -ひずみ関係を $\sigma=F \varepsilon^{n}$ として近似する . パンチの 形状は実験工具の形状と同一とし，剛体として解析を行う.

\section{3. 実験結果および考察}

\section{1 加工力}

加工力は Fig. 1 に示すロードセル〕によって測定される . 測定した加工力を Fig. 5 に示す .ここで，一つの山は一回 打撃の加工力の変動を示している . 一回目の加工力は大き く, 兴の後, 加工力は徐々に減少し定常に至る .これは, 打撃回数の増加に伴い, 打撃面積と押込み量が変化するこ とが原因である .一回目の打撃では, パンチの幅全体で打 撃するため, 加工力は大きい .この場合 , パンチと光の支 持部の弾性変形により, 設定した押込み量まで打撃されな い. 二回目の打撃では，新たに打撃される部分は打撃ピッ チ $p$ の幅だけであるため, 加工力は減少する .この際 , 一 
回目の打撃部も再度打撃されるため, 押込み量は一回目に 比べ, 大きくなるが, 設定値には達していない . このよう に打撃を繰り返すことによって加工力が減少するとともに， 押込み量は徐々に増加し, 定常状態に至る . 定常状態では 打撃ピッチ $p$ の幅だけ塑性変形が行われる . 本研究では, パンチが定常的に平板を打撃する時の加工力の平均值を平 均加工力 $P_{a}$ と定め, 平均加工力を用いて加工力を評価する .

打撃ピッチ $p$ をパラメータにし，打撃角度が平均加工力 $P_{a}$ に及ぼす影響を Fig. 6 に示す.平均加工力 $P_{a}$ は打撃角度 $\alpha$ 23 度までは急激に減少し，打撃角度 $\alpha$ が 3 度を超えると 変化は小さくなる.これは打撃角度 $\alpha$ ンチの打撃角度の増加に従い, 打撃される平板の内側厚さ が小さくなり，打撃される材料の断面積が小さくなるため である．ただし，打撃角度 $\alpha$ 3 度を越えると，パンチに 打撃される平板の断面積の減少率はわずかとなる. 炎のた め, 平均加工力 $P_{a}$ は打撃角度 $\alpha$ が 3 度までは急激に減少し， 打撃角度 $\alpha$ が 3 度を超えると变化は小さくなる．

\section{2 曲げ半径に及ぼす影響}

打撃ピッチ $p$ をパラメータに取り，打撃角度 $\alpha$ 曲げ半 径 $r_{\mathrm{e}}$ に及ぼす影響を Fig. 7 に示す . 外側曲げ半径を用い， 曲げ半径を評価する．打撃角度 $\alpha$ の増加に伴い， $\alpha$ 2 度ま

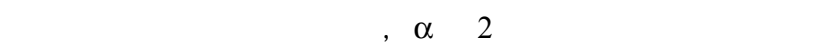
は増加する . 押込み量 $s$ が $0.73 \mathrm{~mm}$ に対し，打撃角度 $\alpha$ が 2 度以下では平板の幅全体がパンチに打撃され, 打撃角度の 増加に伴い，打撃される平板の内側の押込み量が小さくな るため, 内側円周方向ひずみは急激に減少する . 炎れに対 し, 打撃角度が 2 度以上では平板の幅か部分的に打撃され， 打撃角度の増加に伴い，打撃されない平板の幅か増加し， 円周方向変形に対する抵抗か増加するため, 外側円周方向 ひずみが小さくなる . そこで, 曲げ後の外側と内側の円周

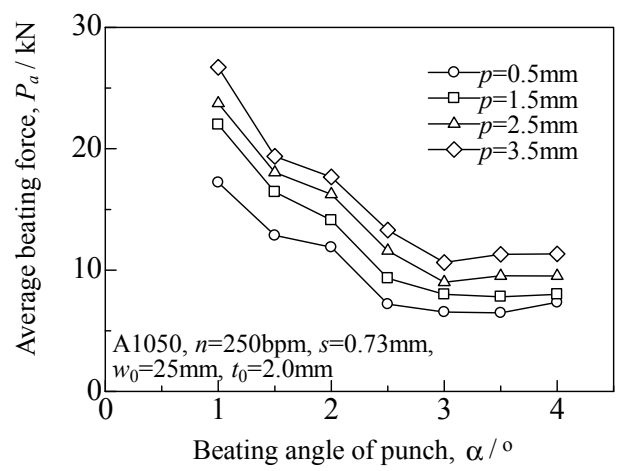

Fig. 6 Effect of beating angle on average beating force

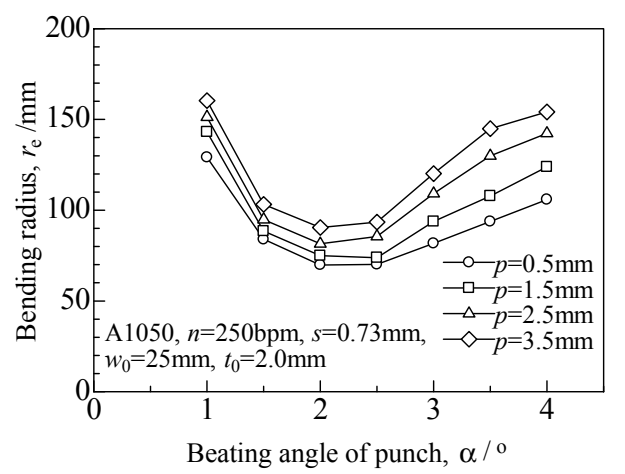

Fig. 7 Effects of beating angle on outer bending radius

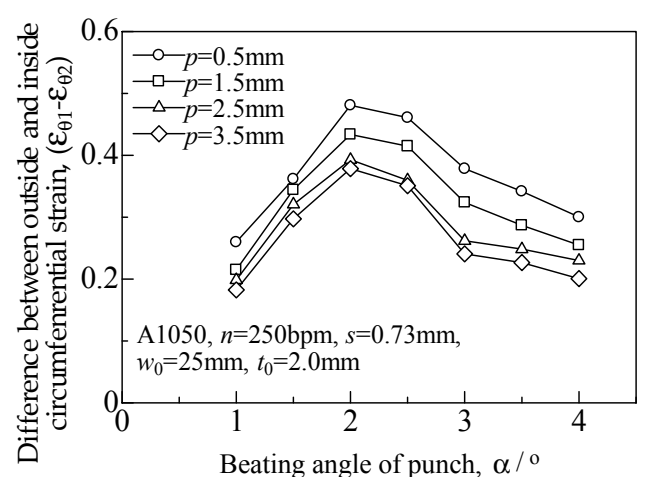

Fig. 8 Effect of beating angle on circumferential strain

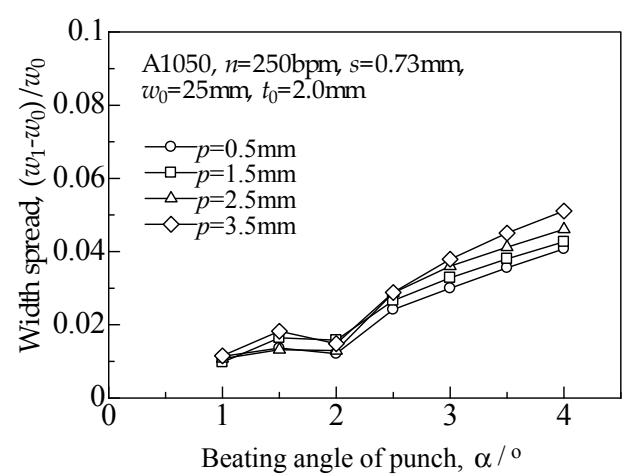

Fig. 9 Effect of beating angle on width spread

方向の曲げひずみの差を調べた結果を Fig. 8 に示す . 外側 と内側の円周方向ひずみの差は, 打撃角度 $\alpha$ が 2 度までは 増加するが, 打撃角度接 2 度を超えると，ひずみの差は 徐々に減少する．このため, 打撃角度 $\alpha$ の増加に伴い, 打 撃角度 $\alpha$ 2 度までは曲げ半径は増加するが, 打撃角度 $\alpha$ が 2 度を超えると曲げ半径は減少する．

\section{3 平板の幅広がり}

打撃ピッチ $p$ をパラメータとし, 打撃角度が平板の広が り $\left(w_{1}-w_{0}\right) / w_{0}$ に及ぼす影響を Fig. 9 に示す .ここで， $w_{1}$ は 加工後の平板の幅である. 打撃角度 $\alpha$ 増加に伴い, 打撃 角度 $\alpha$ 2 度までは幅広がりはわずかであるが, 打撃角度 $\alpha$ が 3 度を超えると急激に増加する．打撃角度 2 度までは幅 全体か打撃され, 板厚ひずみがほぼ円周方向ひずみに変化 するため, 幅広がりの変化は小さい，ただし，打撃角度が 2 度を超えると，パンチの打撃角度 $\alpha$ 増加すると共に打撃 されない部分か増加し, 円周方向の変形を拘束するため, 幅広がりが増加する .

\section{4. 解析結果}

実験と同樣に押込み量を $s$ が $0.73 \mathrm{~mm}$ に，打撃ピッチ $p$ を $1.2 \mathrm{~mm}$ に固定し，打撃角度 $\alpha$ を 1 度から 4 度まで 0.5 度 毎に変化させ , 面内曲げ加工の数値解析を行った . 数值解 析により, 打撃角度の変化が面内曲げ加工の挙動に及ぼす 影響を検討する . また , 板厚方向, 円周方向と幅方向三方 向ひずみの分布についても詳細な検討を実施し，面内曲げ のメカニズムについて考察する .

4. 1 曲げ半径

数值解析によって打撃角度が曲げ半径に及ぼす影響を求 めた結果を Fig.10に示す.実験結果と同樣に，パンチの打 
撃角度 $\alpha$ 増加に伴い, $\alpha$ 2 度までは曲げ半径は減少する が, $\alpha$ 代 2 度を超えると曲げ半径は増加する.つまり，打 撃角度が 2 度近傍で最小の曲げ半径を得る.打撃角度 $\alpha$ 2 度付近では実験とシミュレーションで得た曲げ半径はほぼ 一定であるが，打撃角度が 2 度から両サイドに向かって， 実験で得た曲げ半径とシミュレーションで得た曲げ半径の 差は大きくなる . その原因を調べるために , 打撃角度が 1 度の時の曲げ後平板の打撃面の形状を測定し，兴の打撃面 の板厚分布を Fig. 11 に示す .ここで, $y$ は曲げ後の平板の 外側側面を $y=0$ とし, 外側側面から内側に向かっての距離 である．打撃角度が 1 度では実験とシミュレーションで得 た打撃面の形状にずれが生じる．つまり，打撃される平板 の傾きとパンチの打撃角度が解析と実験で異なっている。 そこで, パンチの打撃角度の变化による平板の傾きを調べ た結果を Fig. 12 に示す．打撃角度の増加に伴い，打撃され

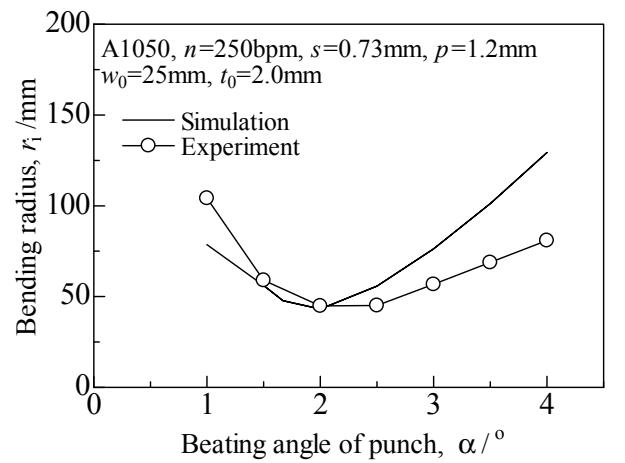

Fig. 10 Comparison of experimental bending radii with simulated bending radii

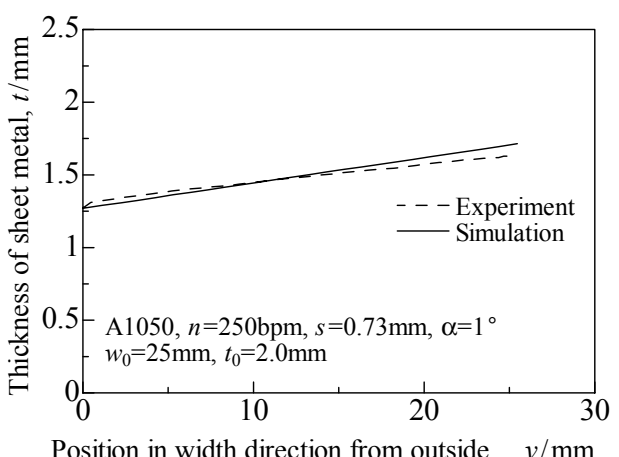

Fig. 11 Thickness distribution of sheet metal at beating angle $\alpha=1$ degree

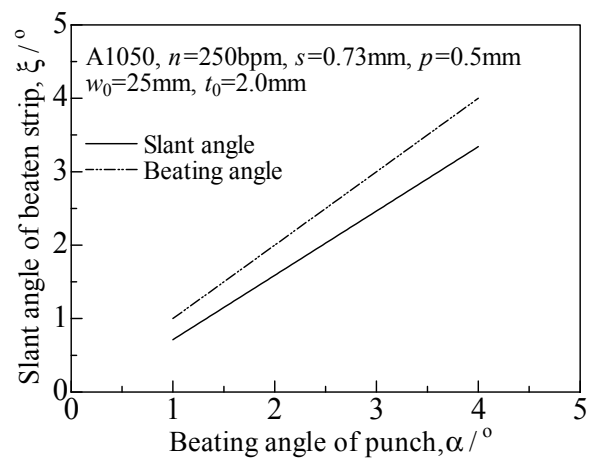

Fig. 12 Difference between beating angle and slant angle of beaten sheet metal

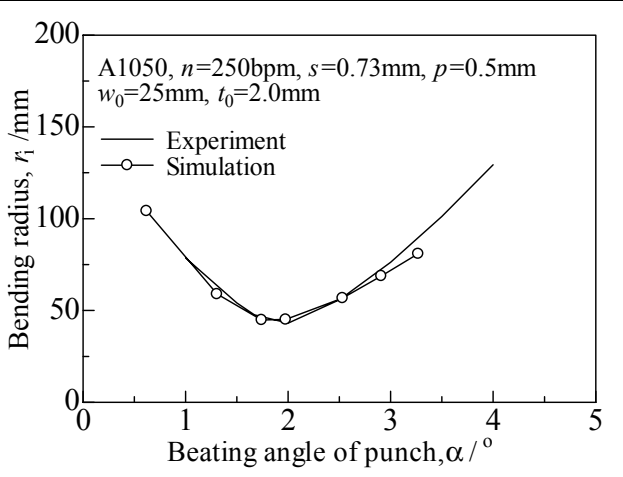

Fig. 13 Comparison of experimental bending radii obtained by real beating angle with simulated bending radii

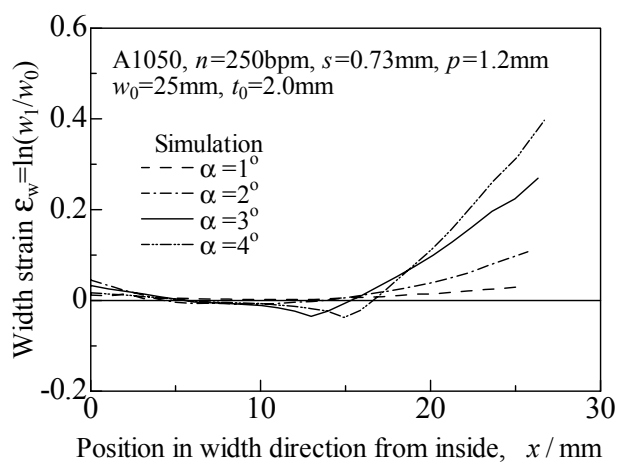

Fig. 14 Distribution of width strain in width direction

る平板の傾きと打撃角度の差は大きくなる . これは , 平板 を打撃する時，平板の反力により，パンチを回転させるモ ーメントが生じ, 打撃される平板の角度が小さくなるため である.

実験で実際に打撃された平板の傾きを測定し，解析での 打撃角度として，曲げ半径を求めた結果を Fig. 13 に示す。 解析結果は実験結果にほぼ一致する . 押込み量 $0.73 \mathrm{~mm}$ に 対し, 打撃角度が 2 度の時に打撃される平板の傾きは平板 の幅全域を打撃するための臨界角度 $\tan ^{-1}\left(s / w_{0}\right)$ に一致する .

\section{2 幅広がり}

Fig. 14 に平板の幅方向への幅方向ひずみの変化分布を 示す.ここで $x$ は曲げ後の平板の内側側面を $x=0$ とし, 内 側側面から外側に向かっての距離である . 全体の傾向とし て, 外側の幅方向ひずみは大きく，内側に向って小さくな る 外周面 $x$ が $25 \mathrm{~mm}$ で幅方向ひずみは最大值を取り $x$ の 減少とともに, $x$ が $17 \mathrm{~mm}$ まで単純に減少していく $x$ が $17 \mathrm{~mm}$ から $6 \mathrm{~mm}$ までの範囲では幅方向ひずみは圧縮され， $x$ が $14 \mathrm{~mm}$ の近傍で極小值を取る. 光の後, $x$ が $6 \mathrm{~mm}$ 以下 の範囲では内側に向かって再び幅方向ひずみは大きくなる． 平板の内側では，打撃角度 $\alpha$ が幅方向ひずみに及ぼす影響 は小さい，一方，外側と中心部では，打撃角度の影響は大 きく，打撃角度の増加に伴い，幅方向ひずみは外側で増加 し，中心部での極小值は小さくなる．

ここで , 板厚方向 , 円周方向と幅方向ひずみの幅方向分

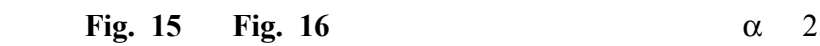
度と 4 度の場合である. 塑性変形では体積変化がないとい う仮定から

$$
\varepsilon_{\mathrm{t}}+\varepsilon_{\mathrm{w}}+\varepsilon_{\theta}=0
$$

となる . 打撃部では板厚ひずみ , 円周方向ひずみと幅方向 


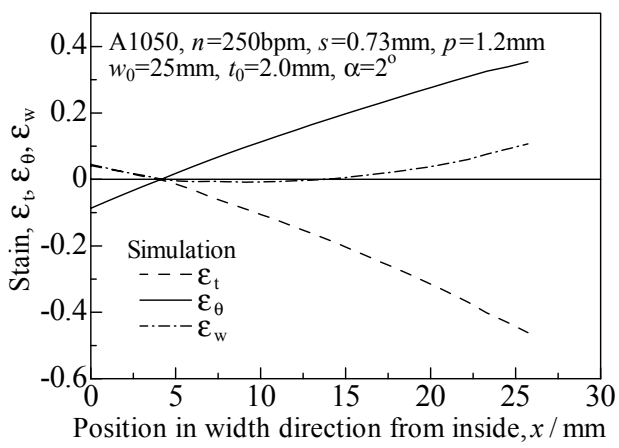

Fig. 15 Distribution thickness strain, circumferential strain and width strain at beating angle $\alpha=2$ degree by simulation

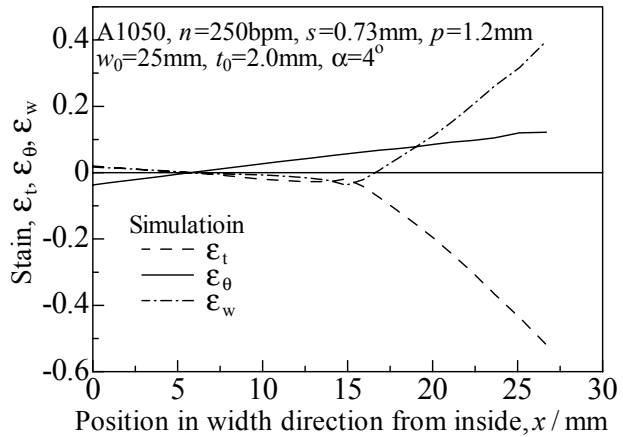

Fig. 16 Distribution thickness strain, circumferential strain and width strain at beating angle $\alpha=4$ degree by simulation

ひずみは以下のようになる .

$$
\varepsilon_{\mathrm{t}}=-\left(\varepsilon_{\mathrm{w}}+\varepsilon_{\theta}\right), \quad\left|\varepsilon_{\mathrm{t}}\right|>\left|\varepsilon_{\mathrm{w}}\right|,\left|\varepsilon_{\theta}\right|
$$

つまり, 板厚方向の変形が原因となり, 円周方向と幅方向 の変形が生じる .これに対して非打撃部では, 幅方向の板 厚ひずみ, 円周方向ひずみと幅方向ひずみは以下のように なる .

$$
\varepsilon_{\theta}=-\left(\varepsilon_{\mathrm{w}}+\varepsilon_{\mathrm{t}}\right), \quad\left|\varepsilon_{\theta}\right|>\left|\varepsilon_{\mathrm{t}}\right|,\left|\varepsilon_{\mathrm{w}}\right|
$$

つまり, 外側円周方向の変形によって生じる, 円周方向の 変形が原因になり, 板厚方向と幅方向の変形が生じる．光 のため, 平板の中央部では幅方向に圧縮変形が生じる . 平 板の内側，すなわち中立面から内側に向って，円周方向の 圧縮変形によって, 厚さの膨らみと幅方向ひずみが生じる． このように FEM 解析で見ると, 板厚ひずみ, 円周方向ひ ずみと幅方向ひずみは，内側から距離 $x$ に伴って変化する. また ,Fig. 15 と Fig. 16 を比べると，打撃角度の増加に伴い， 外側の幅方向ひずみが急激に増加し, 円周方向ひずみは小 さくなる . パンチの打撃角度 $\alpha$ が増加すると共に , 打撃さ れない部分が増加し，円周方向への伸びに対する抵抗が大 きくなるため，円周方向への材料の流動が抑制され，抵抗 が少ない幅方向に材料が流動し，幅広がりが増加する．

以上をまとめると，打撃角度の増加に伴い，増加する平 板の幅広がりと極値を有する曲げ半径を考え，一定の押込 み量に対し，平板の幅全域を打撃する臨界角度が最適な打 撃角度であることがわかった .

\section{5. 結 言}

考案した逐次打点曲げ加工法を面内曲げ加工に適用し， 打撃角度が加工特性に及ぼす影響について, 実験および数
值解析によって検討し，以下のことを得た.

1) 打撃角度か増加すると, 加工力は減少する.

2) 打撃角度の増加に伴い, 幅方向ひずみは増加する . 幅全 体的の幅広がりは小さいものの, 最外周面では幅方向 ひずみは大きい .

3) 押込み量 $0.73 \mathrm{~mm}$ に対し，打撃角度が 2 度近傍，つまり 平板の幅全域を打撃するための臨界角度において, 最 小の曲げ半径を得ることができる．打撃角度が臨界角 度より小さい場合, 平板全体が打撃され, 両サイドが 延び曲げ半径は大きくなるのに対し，臨界角度より大 きい場合平板の外側か打撃され，打撃されない平板の 幅か増加し , 曲げ半径は大きくなる.

曲げ半径を求めるのは, パンチの押込み量と打撃角度の 操作性から打撃角度を一定の条件，つまり最もよく曲がる 条件にし，パンチの押込み量を制御すべきである。

\section{謝 辞}

“ELFEN”による数値解析技法に関する助言を賜りまし た英国 Wales 大学 Rockfield Software Limited に厚くお礼を 申し上げます。

\section{参 考 文 献}

1) 楊明・島進：塑性と加工，32-370 (1987)，1377-1382.

2) 楊明 · 小島直樹·真鍋健一・西村尚 : 同上 ,39-449 (1998), 585-590.

3) 楊明·北川要介·真鍋健一: 同上 ,38-440 (1997), 829-833.

4) 張恩祥·小山秀夫·中村雅勇·芳我功: 同上, 40-458(1999), 235-239.

5) 日本塑性加工学会 : 塑性加工シリーズ 14 , 曲げ加工， (1995)，82，コロナ社.

6) 横山俊雄·長嶋一: 塑性と加工,39-448 (1998), 483-487 .

7) 中村敬一·浅尾宏·渡辺忍・川田陽一: 同上 ,30-340(1989), 651-657.

8) 坂木修次 : 同上 , 28-313 (1987)，128-134.

9) 坂木修次 - 内海能亜 : 同上, 35-397 (1994) , 170-175.

10) 中田孝 : 精密機械, 44-9 (1978)，100-106.

11) 落合和泉: 薄板構造物の加工, 日刊工業新聞社 (1998), 96-114.

12) 渡辺忍・緑川正和・黑川武雄 , 村上碩哉 : 塑性と加工, 35-407 (1994) , 1394-1399.

13) 山田收 ·村上碩哉・高崎光弘, 鎌田充也 : 31 回塑加連 講論, 321 (1980)，427-430.

14) 山田收·村上碩哉·高崎光弘: 塑性と加工 ,30-336(1989), $37-42$.

15) 山田收 - 村上碩哉 - 高崎光弘 : 同上 , 28-313(1987), 194-199.

16）金英俊·村田眞 - 久保木孝：軽金属，54-7(2004), 287-291.

17) Jin, Y., Kuboki, T. \& Murata, M.:J. Mater. Process. Technol.,162-163C(2005), 190-195.

18）金英俊·村田眞 ·久保木孝 : 軽金属, 56-3(2006),145-149. 